\title{
Underdiagnosis of cervical intraepithelial neoplasia (CIN) 2 or Worse Lesion in Women with a Previous Colposcopy-Guided Biopsy Showing CIN 1
}

\section{Subdiagnóstico de neoplasia intraepitelial cervical (NIC) 2 ou lesão mais grave em mulheres com biópsia dirigida por colposcopia prévia mostrando NIC 1}

\author{
${ }^{1}$ Department of Obstetrics and Gynecology, Faculdade de Ciências \\ Médicas, Universidade Estadual de Campinas (UNICAMP), Campinas, \\ São Paulo, Brazil \\ 2 Laboratory of Cytopathology, Faculdade de Ciências Farmacêuticas, \\ Universidade de São Paulo, São Paulo, Brazil \\ 3 Policlínica II, Campinas, São Paulo, Brazil \\ ${ }^{4}$ Department of Pathology, Faculdade de Ciências Médicas, UNICAMP, \\ Campinas, São Paulo, Brazil
}

Carlos André Scheler de Souza ${ }^{1}$ Michelle Garcia Discacciati ${ }^{2}$ Maria Gabriela d'Otavianno ${ }^{1}$ Silvia Maria Bergo ${ }^{3}$ Markus Traue ${ }^{3}$ Liliana Aparecida Lucci de Angelo Andrade ${ }^{4} \quad$ Luiz Carlos Zeferino $^{1}$

Address for correspondence Luiz Carlos Zeferino, MD, PhD, Rua Alexander Fleming, 101, Cidade Universitária Zeferino Vaz, 13083881 Campinas, SP, Brazil (e-mail: zeferino@fcm.unicamp.br).

Rev Bras Ginecol Obstet 2017;39:123-127.

\begin{abstract}
Keywords

- colposcopy

- cervical intraepithelial neoplasia

- colposcopic surgical procedures

- uterine cervical neoplasms

- biopsy

Objective Expectant follow-up for biopsy-proven cervical intraepithelial neoplasia (CIN) 1 is the current recommendation for the management of this lesion. Nevertheless, the performance of the biopsy guided by colposcopy might not be optimal. Therefore, this study aimed to calculate the rate of underdiagnoses of more severe lesions in women with CIN 1 diagnosis and to evaluate whether age, lesion extent and biopsy site are factors associated with diagnostic failure.

Methods Eighty women with a diagnosis of CIN 1 obtained by colposcopy-guided biopsy were selected for this study. These women were herein submitted to large loop excision of the transformation zone (LLETZ). The prevalence of lesions more severe than CIN 1 was calculated, and the histological diagnoses of the LLETZ specimens were grouped into two categories: "CIN 1 or less" and "CIN 2 or worse."

Results The prevalence of lesions diagnosed as CIN 2 or worse in the LLETZ specimens was of $19 \%(15 / 80)$. Three women revealed CIN 3, and 1 woman revealed a sclerosing adenocarcinoma stage I-a, a rare type of malignant neoplasia of low proliferation, which was not detected by either colposcopy or previous biopsy. The underdiagnosis of CIN 2 was not associated with the women's age, lesion extension and biopsy site.

Conclusions The standard methods used for the diagnosis of CIN 1 may underestimate the severity of the true lesion and, therefore, women undergoing expectant management must have an adequate follow-up.
\end{abstract}

received

September 15, 2016

accepted

December 19, 2016

published online

March 6, 2017
DOI http://dx.doi.org/

10.1055/s-0037-1599071. ISSN 0100-7203.
Copyright (c) 2017 by Thieme-Revinter

Publicações Ltda, Rio de Janeiro, Brazil
License terms

(c) $(1) \$$ 


\section{Resumo}

Palavras chaves
- colposcopia
- neoplasia
intraepitelial cervical
- procedimentos
cirúrgicos
colposcópicos
- neoplasias do colo do
útero
- biópsia

Objetivo O seguimento de mulheres com neoplasia intraepitelial cervical (NIC) 1 comprovada por biópsia é atualmente a recomendação de conduta para esta lesão. Entretanto, o desempenho da biópsia guiada por colposcopia pode falhar. Assim, este estudo teve como objetivo estimar a taxa de subdiagnóstico de lesões mais graves em mulheres com diagnóstico de NIC 1 e avaliar se a idade, a extensão da lesão e o local da biópsia são fatores associados à falha do diagnóstico.

Métodos Foram selecionadas 80 mulheres com diagnóstico de NIC 1 obtido por biópsia dirigida por colposcopia. Estas mulheres foram submetidas a excisão da zona de transformação por alça diatérmica (EZTAD). A prevalência de lesões mais graves do que NIC 1 foi calculada, e os diagnósticos histológicos feitos nas amostras obtidas por EZTAD foram agrupados em duas categorias: "NIC 1 ou menos grave" e "NIC 2 ou mais grave".

Resultados A prevalência de lesões diagnosticadas como NIC 2 ou mais grave nas amostras de EZTAD foi de 19\% (15/80). Três mulheres apresentaram NIC 3, e uma mulher revelou adenocarcinoma esclerosante estágio l-a, um tipo raro de neoplasia maligna de baixa proliferação, que não foi detectado por qualquer exame de colposcopia ou biópsia anterior. O subdiagnóstico de NIC 2 não foi associado à idade, à extensão da lesão ou ao local da biópsia.

Conclusão Os métodos de referência utilizados para o diagnóstico da NIC 1 podem subestimar a gravidade da lesão verdadeira e, portanto, as mulheres submetidas a conduta expectante devem ter um seguimento adequado.

\section{Introduction}

Cervical intraepithelial neoplasia (CIN) 1 is a highly prevalent lesion in young women, and its prevalence is decreasing with age. $^{1}$ Around $90 \%$ of the cases are associated with high-risk human papillomavirus (HPV); however, the regression rates of these lesions may reach up to $80 \%^{2,3}$ Expectant management with colposcopy and/or cytology follow-up has been proposed for CIN 1 , since the probability of this lesion progressing to invasive carcinoma is low. ${ }^{3-6}$ The objective of this clinical approach is to reduce the rate of unnecessary surgical procedures that may involve morbidities, such as risk of impaired fertility and obstetric outcome. ${ }^{7-10}$ Metaanalysis studies showed that cold knife conization and large loop excision of the transformation zone (LLETZ) are associated with poorer obstetric outcomes related to preterm delivery and low birthweight. ${ }^{10,11}$

Nevertheless, there is a concern with respect to the precision of the histological diagnosis of CIN 1, since biopsy, even if directed to the most suspected areas identified by the colposcopist, consists of the analysis of a relatively small tissue sample that depends on several factors, such as the colposcopist's skills and the interobserver variability intrinsic to this procedure. ${ }^{12}$ A possible error resulting from conservative management is to diagnose CIN 1 when the woman actually has a more severe lesion. Therefore, the objective of this study was to re-evaluate cervical lesions in women with a previous histological diagnosis of CIN 1 established by colposcopy-guided biopsy. The same patients were thus submitted to LLETZ to investigate if CIN 2, CIN 3 or cervical cancer lesions were underdiagnosed. We also evaluated whether age, lesion extent and biopsy site are factors associated with diagnostic failure.

\section{Methods}

This analysis is derived from a Brazilian casuistic of randomized trial to evaluate expectant management versus immediate treatment for low-grade CIN performed between January 2003 and March 2006. ${ }^{3}$ The trial included women with previous cytology of low-grade squamous intraepithelial lesion (LSIL) or atypical squamous cells of undetermined significance (ASC-US), with a CIN 1 diagnosis revealed by colposcopy-guided biopsy. Eighty women consecutively randomized to undergo immediate treatment by LLETZ were included in this analysis. The LLETZ was performed up to 45 days after the CIN 1 diagnosis. ${ }^{3}$

Women were selected based on their cervical smear test routinely performed as part of a cervical cancer screening program. Patients were excluded for any of the following: unsatisfactory colposcopy; current pregnancy; prior therapy for dysplasia, including medical (5-FLUROURACIL), surgical (laser, loop electrosurgical excision procedure [LEEP]), or cryotherapy; prior gynecologic cancer; prior pelvic radiation therapy; other malignancies; immunosuppression due to diseases such as AIDS, organ transplantation, or use of immunosuppressive medications; cognitive impairment or inability to provide written informed consent.

For the colposcopic examination, the cervix was divided into four quadrants; the two anterior quadrants were 
considered as the anterior lip of the cervix, and the other two as the posterior lip. The extension of the lesion was recorded according to the number of compromised quadrants of the cervix. The site selected for the biopsy was the one identified by the colposcopist as being the most suspicious. The excision of the transformation zone was performed using a diathermic loop to a depth of $\sim 5 \mathrm{~mm}$ to include the entire lesion identified. The histopathology of the biopsy and the conization were analyzed by the same pathologist.

For the purpose of analysis, the LLETZ histological diagnoses were allocated into two groups: "no neoplasia/CIN 1" and "CIN 2 or worse (CIN $2+$ )". The associations between the LLETZ histological diagnosis and the age of the woman, the extension of the lesion and the site of biopsy were analyzed. The median age was 24 years; therefore, the women were also grouped into "younger than 24 years" and " 24 or older". The magnitude of the associations was tested by odds ratios (ORs) and their respective 95\% confidence intervals (95\%CIs). This study was approved by the Internal Review Board of Faculdade de Ciências Médicas of Universidade Estadual de Campinas (number 023/2003).

\section{Results}

The LLETZ confirmed that 54\% (43/80) of the patients had CIN 1 , and no neoplasia was found in $28 \%(22 / 80)$ of the specimens (-Table 1). Cervical intraepithelial neoplasia 2 or worse in the LLETZ specimens was detected in 19\% (15/80) of the women. Within this group, 3 women, aged 19, 22 and 40 (data not shown in tables), had a diagnosis of CIN 3 in the LLETZ specimen. There was one woman for whom the LLETZ specimen revealed a "sclerosing adenocarcinoma" stage I-a, a rare type of malignant neoplasia of low proliferation, which was not detected by either colposcopy or previous biopsy. This cancer was located in the cervical canal, and the LLETZ
Table 1 Distribution of histological diagnoses obtained from LLETZ specimens for women with CIN 1 established by colposcopy-guided biopsy

\begin{tabular}{|l|l|}
\hline Histological diagnosis & $\mathbf{n}(\%)$ \\
\hline No neoplasia & $22(27.5)$ \\
\hline CIN 1 & $43(53.8)$ \\
\hline CIN 2 & $11(13.8)$ \\
\hline CIN 3 & $3(3.8)$ \\
\hline Malignant neoplasia* & $1(1.3)$ \\
\hline Total & $80(100)$ \\
\hline
\end{tabular}

Abbreviations: CIN, cervical intraepithelial neoplasia; LLETZ, large loop excision of the transformation zone.

Note: *Sclerosing adenocarcinoma stage l-a located at the cervical canal.

specimen revealed a positive endocervical margin, and the radical hysterectomy showed no residual disease.

- Table 2 shows that lesions extending to two or more quadrants were present in $34 \%$ of the women, but this finding was not significantly associated with the presence of CIN $2+$ in the LLETZ specimens. Moreover, no significant association was found between the severity of the lesions and the age group or the biopsy site. Biopsies were performed in the anterior cervical lip in most cases $(n=43)$.

\section{Discussion}

This study found $19 \%$ of CIN 2 or worse in women with previous diagnosis of CIN 1 in colposcopy-guided biopsies. This result suggested that the colposcopy-guided biopsy samples are not always representative of the severity of the lesions, and that has been observed for the colposcopic

Table 2 Association between the histological diagnosis of the LLETZ specimens with age, lesion extension and biopsy site for women with CIN 1 established by colposcopy-guided biopsy

\begin{tabular}{|c|c|c|c|}
\hline & \multicolumn{3}{|l|}{ Histological diagnosis } \\
\hline & $\begin{array}{l}\text { No neoplasia/CIN } 1 \\
\text { n (\%) }\end{array}$ & $\begin{array}{l}\text { CIN 2+ } \\
\text { n (\%) }\end{array}$ & OR $(95 \% \mathrm{Cl})$ \\
\hline \multicolumn{4}{|l|}{ Age group } \\
\hline$<24$ years & $33(51)$ & $10(67)$ & \multirow[t]{2}{*}{$1.93(0.59-6.30)$} \\
\hline$\geq 24$ years & $32(49)$ & $5(33)$ & \\
\hline \multicolumn{4}{|l|}{ Extent of the lesion ${ }^{a}$} \\
\hline One quadrant & $42(66)$ & $9(70)$ & \multirow[t]{2}{*}{$0.85(0.19-3.52)$} \\
\hline Two or more quadrants & $22(34)$ & $4(30)$ & \\
\hline \multicolumn{4}{|l|}{ Site of the biopsy ${ }^{b}$} \\
\hline Anterior lip & $38(60)$ & $5(33)$ & \multirow[t]{2}{*}{$2.92(0.79-11.29)$} \\
\hline Posterior lip & $26(40)$ & $10(66)$ & \\
\hline
\end{tabular}

Abbreviations: $95 \% \mathrm{Cl}$, 95\% confidence interval; CIN, cervical intraepithelial neoplasia; LLETZ, large loop excision of the transformation zone; OR, odds ratio.

Notes: anformation was missing for one woman with "No neoplasia/CIN 1" and two women with "CIN $2+$ ".

bInformation was missing for one woman with "No neoplasia/CIN 1". 
examination. ${ }^{13}$ Another issue that should be considered is the observer variability regarding the CIN 1 histological diagnosis, as well as the interlaboratory variability. ${ }^{12,14}$ Following a prospective two-year follow-up, the Atypical Squamous Cells of Undetermined Significance/Low-Grade Squamous Intraepithelial Lesions Triage Study (ALTS) reported 13\% of CIN 2 and CIN 3 in patients with an initial histological diagnosis of CIN $1 ; 11.3 \%$ had a previous normal colposcopy, and $11.7 \%$ had a previous negative biopsy. ${ }^{15}$ Boonlikit et $\mathrm{al}^{16}$ reported an agreement rate between biopsy and LLETZ of $66 \%$ (Kappa $=0.24$; fair agreement) in women under 50 years of age. Nevertheless, the biopsy failure rate seems to decrease with the increasing severity of the histological diagnosis. ${ }^{17}$

In our study, we found $53.8 \%$ of agreement for CIN 1 diagnosis, and $18.7 \%$ of underdiagnosis. The remaining $27.5 \%$ of the cases showed no neoplasia, which could be a consequence of the total removal of the lesion by the colposcopyguided biopsy, or a regression of the lesion due to the clearance of the HPV infection.

No association was found between age and the presence of CIN 2 or worse in the LLETZ specimens. Studies have shown that the CIN 3 prevalence is higher in older women not enrolled in the cervical cancer screening, while age is not a determinant factor in women with previous screening tests. ${ }^{1}$ Indeed, the women in this study were previously subjected to cervical cancer screening and, therefore, we did not find a high prevalence rate of more severe lesions in older women, as expected.

The extension of the lesion at colposcopy and the site of the biopsy were not associated with CIN 2 or worse at the LLETZ, that is, these factors were not associated with diagnostic failure. This finding suggests that, in the case of more extensive lesions, the efficacy of colposcopy in selecting the biopsy site was similar to that found when the lesions were confined to one quadrant. Studies have shown that the number of biopsies can increase the performance of the colposcopy-guided biopsy. Pretorius et al $^{18}$ reported $43 \%$ of undetected high-grade lesions when performing only one colposcopy-guided biopsy, and they suggested that diagnosis would be more precise if random biopsies or endocervical canal curettage were performed. Moss et $\mathrm{al}^{19}$ concluded that single colposcopically directed punch biopsy appears to be insufficient to exclude underlying CIN 2 or 3 in women with an ASC-US or LSIL cytological result and minor colposcopic findings. Increasing the number of biopsies increases the detection rate of CIN 3, and random biopsies from apparently normal cervical tissue increase the chance of finding hidden lesions. ${ }^{20,21}$

Our study diagnosed $19 \%$ of CIN 2 or worse in women with previous diagnosis of CIN 1 in colposcopy-guided biopsies, and these findings are relevant mainly for younger women, for whom a more conservative approach must be considered. However, such an approach does not seem to affect the clinical success of the expectant management of CIN 1, as shown by a previous clinical trial. ${ }^{3}$ Considering that the current recommendation for CIN 1 management is followup without treatment, the colposcopic examination should reach high performance to offer a reasonable guarantee that the woman does not have worse lesions. If the patient is adequately followed-up, a more severe lesion might be detected at the control visits, which could minimize the occurrence of underdiagnosis of CIN lesions.

\section{References}

1 Vale DB, Westin MC, Zeferino LC. High-grade squamous intraepithelial lesion in women aged $<30$ years has a prevalence pattern resembling low-grade squamous intraepithelial lesion. Cancer Cytopathol 2013;121(10):576-581

2 Zuna RE, Wang SS, Rosenthal DL, Jeronimo J, Schiffman M, Solomon D; ALTS Group.Determinants of human papillomavirus-negative, low-grade squamous intraepithelial lesions in the atypical squamous cells of undetermined significance/lowgrade squamous intraepithelial lesions triage study (ALTS). Cancer 2005;105(05):253-262

3 Elit L, Levine MN, Julian JA, et al. Expectant management versus immediate treatment for low-grade cervical intraepithelial neoplasia : a randomized trial in Canada and Brazil. Cancer 2011; 117(07):1438-1445

4 Saslow D, Solomon D, Lawson HW, et al; American Cancer Society; American Society for Colposcopy and Cervical Pathology; American Society for Clinical Pathology. American Cancer Society, American Society for Colposcopy and Cervical Pathology, and American Society for Clinical Pathology screening guidelines for the prevention and early detection of cervical cancer. Am J Clin Pathol 2012;137(04):516-542

5 Ostör AG. Natural history of cervical intraepithelial neoplasia: a critical review. Int J Gynecol Pathol 1993;12(02):186-192

6 Wright TC Jr, Massad LS, Dunton CJ, Spitzer M, Wilkinson EJ, Solomon D; 2006 American Society for Colposcopy and Cervical Pathology-sponsored Consensus Conference. 2006 consensus guidelines for the management of women with cervical intraepithelial neoplasia or adenocarcinoma in situ. Am J Obstet Gynecol 2007;197(04):340-345

7 Wright TC Jr, Cox JT, Massad LS, Carlson J, Twiggs LB, Wilkinson EJ; American Society for Colposcopy and Cervical Pathology. 2001 consensus guidelines for the management of women with cervical intraepithelial neoplasia. Am J Obstet Gynecol 2003;189(01): 295-304

8 Saslow D, Runowicz CD, Solomon D, et al; American Cancer Society. American Cancer Society guideline for the early detection of cervical neoplasia and cancer. CA Cancer J Clin 2002;52(06):342-362

9 Austoker J, Bankhead C, Davey C. Cervical screening results explained: a guide for primary care. London: National Health System (NHS); 2003

10 Kyrgiou M, Koliopoulos G, Martin-Hirsch P, Arbyn M, Prendiville W, Paraskevaidis E. Obstetric outcomes after conservative treatment for intraepithelial or early invasive cervical lesions: systematic review and meta-analysis. Lancet 2006;367(9509):489-498

11 Arbyn M, Kyrgiou M, Simoens C, et al. Perinatal mortality and other severe adverse pregnancy outcomes associated with treatment of cervical intraepithelial neoplasia: meta-analysis. BMJ 2008;337:a1284

12 Stoler MH, Schiffman M; Atypical Squamous Cells of Undetermined Significance-Low-grade Squamous Intraepithelial Lesion Triage Study (ALTS) Group. Interobserver reproducibility of cervical cytologic and histologic interpretations: realistic estimates from the ASCUS-LSIL Triage Study. JAMA 2001;285(11): 1500-1505

13 Mustafa RA, Santesso N, Khatib R, et al. Systematic reviews and meta-analyses of the accuracy of HPV tests, visual inspection with acetic acid, cytology, and colposcopy. Int J Gynaecol Obstet 2016; 132(03):259-265 
14 Gage JC, Schiffman M, Hunt WC, et al; New Mexico HPV Pap Registry Steering Committee. Cervical histopathology variability among laboratories: a population-based statewide investigation. Am J Clin Pathol 2013;139(03):330-335

15 Cox JT, Schiffman M, Solomon D; ASCUS-LSIL Triage Study (ALTS) Group. Prospective follow-up suggests similar risk of subsequent cervical intraepithelial neoplasia grade 2 or 3 among women with cervical intraepithelial neoplasia grade 1 or negative colposcopy and directed biopsy. Am J Obstet Gynecol 2003;188(06): 1406-1412

16 Boonlikit S, Asavapiriyanont S, Junghuttakarnsatit P, Tuipae S, Supakarapongkul W. Correlation between colposcopically directed biopsy and large loop excision of the transformation zone and influence of age on the outcome. J Med Assoc Thai 2006;89(03): 299-305

17 Sideri M, Garutti P, Costa S, et al. Accuracy of colposcopically directed biopsy: results from an online quality assurance pro- gramme for colposcopy in a population-based cervical screening setting in Italy. BioMed Res Int 2015;2015:614035

18 Pretorius RG, Zhang WH, Belinson JL, et al. Colposcopically directed biopsy, random cervical biopsy, and endocervical curettage in the diagnosis of cervical intraepithelial neoplasia II or worse. Am J Obstet Gynecol 2004;191(02):430-434

19 Moss EL, Hadden P, Douce G, Jones PW, Arbyn M, Redman CW. Is the colposcopically directed punch biopsy a reliable diagnostic test in women with minor cytological lesions? J Low Genit Tract Dis 2012;16(04):421-426

20 Gage JC, Hanson VW, Abbey K, et al; ASCUS LSIL Triage Study (ALTS) Group. Number of cervical biopsies and sensitivity of colposcopy. Obstet Gynecol 2006;108(02):264-272

21 Nam K, Chung S, Kwak J, et al. Random biopsy after colposcopydirected biopsy improves the diagnosis of cervical intraepithelial neoplasia grade 2 or worse. J Low Genit Tract Dis 2010;14(04): 346-351 